\title{
Economic Analysis of Cocoa Production in Ilesha Metropolis of OSUN State
}

\author{
Akinniran, T. N*,Taiwo, K. B.** \\ *Department of Agricultural Economics, LadokeAkintola University of Technology, Ogbomoso, Nigeria \\ **Department of Animal Production and Health, Oyo State College of Agriculture Igboora
}

\begin{abstract}
Before the discovery of oil, agriculture was the main stay of Nigeria economy it was a major component of the gross domestic product (GDP) contributing asmust as $75 \%$ to the country economy. The following cash crops: cocoa, oil palm, groundnuts, timber, rubber as well as staple food crops like rice, maize, millet, beans among others are agricultural products in Nigeria then. With discovery of oil in late fifties, agricultural sector was neglected and the country moved from self-sufficient to one of heavily dependence on importation of food crops such as rice, wheat, rice etc. to feed her populace. Cocoa farmers in Ilesha constitute the sampling frame for the study. A two-stage random sampling technique was used in selecting the respondents for the study. Random sampling technique was used to select Nine (9) cells in the study area, followed by purposive selection of ten (10) cocoa farmers, which gives a sample size of ninety (90) cocoa farmers. Primary data were collected through the use of structured questionnaire and interview schedule. Information collected was analyzed using descriptive statistics, regression analytical tools and budgetary technique to: present the socio-economic characteristics of the respondents,determine the level of relationship between the dependent and independent variables anddetermine the costs and returns, hence profitability of cocoa production. From the findings of this study, the mean age of the cocoa farmers was 55years.It can be deduced that majority of the farmers are still at their active age, hence, production is still expected to be increased. It is necessary to encourage the young farmers into cocoa production to take farming as a lucrative job. Majority of the cocoa farmers had one form of education or others, which implies that, they will be able to adapt to and adopt any form of innovation brought to them that can boast their farming system. The mean 28years of experience indicates that most of the farmers have been into cocoa production for a long period of time; hence, there is probability of increased output. The mean age of the cocoa trees of 27years, indicated thatthere is need to establish new plantation to replace the older ones. More than half of the respondents inherited their cocoa farm. Other crops grown by the cocoa farmers include: citrus, kola, banana and oil palm, to serve as shade for the cocoa seedling and other foreign exchange. Predominantly, most of the cocoa are first harvested at an average age of 5yarsdue to the introduction of improved cocoa hybrids. The major source of capital was personal saving, 61.8 percent use of hired labour for their farm operations, while 93.3\% of the seeding used was raised in nursery. The mean time of harvest is 4 times. In addition, rent on land, cost of seedlings and cost of labour are statistically determine the profitability of cocoa farmers while quantity of fertilizer and increase in farm size determined the cocoa productivity. Hence, cocoa production can be improved if young graduates can be encouraged to embark on farming; rent on land be moderate; costs of seedlings is affordable; coupled with using experienced hired labour and performing the farming operation as at when due.
\end{abstract}

Keywords: cocoa, productivity, profitability, farming experience, foreign exchange

\section{Introduction}

Before the discovery of oil, agriculture was the main stay of Nigeria economy it was a major component of the gross domestic product (GDP) contributing asmust as $75 \%$ to the country economy. The following cash crop's cocoa, oilpalm groundnuts, timber, rubber as well as staple food crops like rice, maize, millet, beans among others are agricultural products in Nigeria then. With discovery of oil in late fifties, agricultural sector was neglected and the country moved from self-sufficient to one of heavily dependence on importation of food crops such as rice, wheat to feed her populace.

Cocoa, Theobromacaocao (L) one of the major cash crops in the country was believed to have originated in the hot humid region near the sources of river amazon in South America. It is still found growingwild along the river amazon and its important tributaries. It was introduced into many countries in West Africa during the nineteenth century, and it has become an important export crop in Ghana, Cote D'ivore, Nigeria, Togo and equatorial Guinea (Folayanet al; 2006) the above mentioned counties supply more than two- thirds of the World's cocoa (Komolafeet al, 1980).

The early development of cocoa industry in West Africa was entirely due to the initiative and entrepreneurship of the West African peasant farmers in Nigeria, the government has developed an interest in 
the cultivation of cocoa since 1887 when cocoa seedling from the old botanic garden at Ebute-meta (Lagos) were set-up for trial (Opeke, 1982).

Cocoa can be grown with on a wide range of rainfall from 100 to $300 \mathrm{~mm}$ per annum or more when irrigation is available and provided that occurrence of dry windsis limited; the crop can be grown without rain. Cocoa is very sensitive to moisture stress. It is also very sensitive to excess water in the soil.In selecting site for planting cocoa; it is desirable to ensure that the site enjoys rainfall averaging $150 \mathrm{~mm}$ per month for at least nine months of the year. The optimal averagetemperature throughout the year for cocoa cultivation is annual $25^{\circ} \mathrm{C}$ with a daily temperature of not more than $10^{\circ} \mathrm{c}$. It has been suggested that daily temperaturefluctuation, of this order are necessary to initiate bud bursting (Opeke, 1982).

In spite of shifts in the national foreign exchange source. Cocoa continues toplay a major role in the economic life of people in the old western region and inrecent years has contributed substantially to the foreign exchange earnings of the nation. Since 1986 when commodity boards were dissolved cocoa trade rose phenomenally assuming a more dynamic economic activity. Currently cocoa provide economic activities for a cross-section of the public both in and outside the production region (Nkanget al; 2006).

Cocoa production is an intensive operation from planting to marketing engaging people of diverse training and experience, with each group occupying a part of its own. Planting, maintenance, harvesting and drying provide jobopportunities for the rural population including the old and aging farmers (men and women) and young school leavers. The quality control marketing processing and exporting provided business for both civil servants, national and international business men (Nkanget al; 2006).

Given the need economic and foreign exchange sources diversification, the fact that cocoa, an agricultural enterprise is capable of sustainability and the need forincreased revenue to the government at federal state and local levels, it is animperative to explore ways to increase cocoa production on a sustainable basis (Akinyemiju, 1995).

The main objective of this paper was centered on economics analysis of cocoa Production in Ilesha East and Ilesha West Local Government Areas. The paper was specifically aimed at: discussing the effect of socioeconomic characteristics of cocoa farmers on their production;determining the relationship between cocoa production input and cocoa output;evaluating the cost and returns hence profitability of cocoa farming; anddetermining the problems associated with cocoa production in the study area.

\section{Methodology}

The study was carried out in Ilesha Metropilis in Ilesha Agricultural Development Programme zone of Osun-State. Until November 1988, ancient city of Ilesha was a single Local Government Area when it was carved into 2 as Ilesha West and Ilesha East Local Government Areas accordingly. Ilesha East Local Government is about $113 \mathrm{~km}^{2}$ in land area and size and it is located along Iyemogun road, while Ilesha West has its headquarters at Ereja. Ilesha West Local Government is about $114 \mathrm{~km} 2$ in land and size.

Ilesha which is $30 \mathrm{~km}$ from Osogbo, Osun state shares boundaries withObokun LGA of Osun State in the North. Oriade LGA in the west, and Atakumosa West LGA in the south. Ilesha is predominately Yoruba apart from Ijesha who are molegenes of the area, other Yoruba speaking people of Oyo, Ekiti, Ijebu, Egba, Igbomina are residing peacefully in every nooks and crannies of the area. In like manner, people from other ethnic groups in Nigeria like the Hausa, Igbo, Edo and other nationalities were exist peacefully within the area.

The major occupation of the people is trading but this is not that people of Ilesa are not practicing farmers. The people in the area specialize in the cultivation of food and cash crops such as yam, cocoa, kolanut, citrus and oil palm and production of livestock animals such as poultry birds pig, cattle and sheep. The income based population was prominently maize farmers.

Cocoa farmers in Ilesha East and West Local Government Areas constitute the sampling frame for the study. A two-stage random sampling technique was used in the cross-sectional surveying of the study area. Random sampling was used to select Nine (9) cells in the study area. In each cell purposive selectionwas used to select ten (10) cocoa farmers, which gives a sample size of ninety (90) cocoa farmers. The reason for the purposiveness is the availability of cocoa farmers in the area.

This research work employed the use of primary data. The data were collected through the use of structured questionnaire and interview schedule. Information on cocoa production and socio - economic characteristics of cocoa farmers were obtained.Data collected were analyzed using both descriptive statistics and regression analytical tools.Descriptive tools include the use of tables, frequencies andpercentage to present the socio-economic characteristics of the respondents.Regression analysis on the other hand, was employed using both Semi-log and Exponential functions to determine the level of relationship between the dependent and independent variables. Also, budgetary technique was used to determine the costs and returns, hence profitability of cocoa production. 
The dependent and independent variables were set into a Semi-log function to determine the relationship between cocoa production input and cocoa output of the cocoa farmers as below:

$\ell^{Y}=A X_{i}^{B i}$

ln of both sides

$\mathrm{Y}=\ln \mathrm{A}+\beta_{\mathrm{i}} \ln \mathrm{X}_{\mathrm{i}}+\ell_{i}$

$\beta_{\mathrm{i}}=$ Coefficient of $\mathrm{X}_{\mathrm{i}}$ (parameters)

$\mathrm{X}_{\mathrm{i}}=$ Explanatory variables

where $\mathrm{i}=1-5$

$\ell_{i}=$ error / disturbance term

The exponential function was established to analyze the productivity of the cocoa farmers in the study area.

$Y=\ell^{A+\beta_{i} X_{i}+\ell_{i}}$

takeln of both sides

$\ln \mathrm{Y}=\mathrm{A}+\beta_{\mathrm{i}} \mathrm{X}_{\mathrm{i}}+\ell_{i}$

$\beta_{\mathrm{i}}=$ Coefficient of $\mathrm{X}_{\mathrm{i}}$

$\mathrm{X}_{\mathrm{i}}=$ Independent variables

$\ell_{i}=$ error terms

where $\mathrm{i}=1-8$

$\mathrm{Y}=$ Total output

$\mathrm{X}_{\mathrm{i}}=$ Chemical

$\mathrm{X}_{2}=$ Fertilizer

$\mathrm{X}_{3}=$ Farm Size/hectare

$\mathrm{X}_{4}=$ Seedlings (input use)

$\mathrm{X}_{5}=$ Labour /Manday

$\mathrm{X}_{6}=$ Age

$\mathrm{X}_{7}=$ Level of Education

$\mathrm{X}_{8}=$ Farming Experience

This research work measures two variables i.e. the dependent and independent variables. The dependent variable was the total output of cocoa per year in the study area. The independent variables are age (years), level of education, farming experience (year), farm size (hectares), age of cocoa (year) labour per manday, litres for chemicals applied per hectares.

\section{Result and Discussion}

Socio-economic characteristics of cocoa production in IlesaMetropolis of Osun State are presented in Table 1. From the table, it was revealed that $88, \%$ of the respondents are male while the remaining $11.2 \%$ are female, indicating that cocoa production in the study area was dominated by males. The mean age of the cocoa farmers was 55years, while the modal age group fell between 41 and 60 years. It can be deduced that majority of the farmers are still at their active age, hence,production is still expected to be increased. It is necessary to encourage the young farmers into cocoa production to take farming as a lucrative job.

From the Table, $36.0 \%$ of the cocoa Farmers had primary education, $23.6 \%$ are secondary school leavers, $19.1 \%$ had tertiary education while 21.3 had no one formal education. This showed that, majority of the cocoa farmers had one form of education or others, which implies that, they will be able to adapt to and adopt any form of innovation brought to them that can boast their farming system. Also majority of the farmers (36.-\%) had between 16 and 30 years of farming experience in cocoa production, the most experienced cocoa farmers with 41 - 45 years was $25.8 \%$ and $24.7 \%$ had between $0-15$ years while only $13.5 \%$ had more 45 years experience in cocoa farming production. The mean 28years of experience indicates that most of the farmers have been into cocoa production for a long period of time, hence, there is probability of increased output.

In addition, $78.7 \%$ of the respondents had between 0 and 3 hectares of farm land under cocoa plantation, $11.2 \%$ had between 4 and 7 hactares, while only $10.1 \%$ had more than 7 hectares farm size. The average farm size of the respondents had approximately 3 heaters, indicating that, most of the cocoa farmers are small scale producers which may be due to some factors like, lack of fund, access to improved inputs, land tenancy etc. 
Other occupations of the cocoa farmers were also iterated, and it was found that $49.6 \%$ are artisans, $16.8 \%$ are civil servants, $4.4 \%$ engage in other farming occupation while $29.2 \%$ shoed no response, indicating that the cocoa farmers also engaged in a series of occupation apart from cocoa farming.

Input Used in cocoa production are presented in Table 2. It could be deduced from the table that $44.9 \%$ and $41.6 \%$ of cocoa trees on the respondent's farms are between the ages of 21 and 40 years and between 0 and 20years respectively the remaining $13.5 \%$ had spent between 41 and 60 years on the farm. The mean age of the cocoa three is 26.99 approximately 27 years. Which is an indication that most of the cocoa trees have spent a long time on the farm and cocoa farming had been in practice for decades in the study area, hence there is need to plant establish new plantation to replace the older ones. It was recorded that $51.7 \%$ of the respondents inherited the cocoa farm, $23.6 \%$ and $14.6 \%$ purchased and leased their farm plantations respectively only $10.1 \%$ acquired their cocoa farm through other means. This implies that more than half of the respondents inherited the cocoa farm. Other crops grown by the cocoa farmers include: citrus, kola, banana and oil palm, which pulled at $12.4 \%, 20.2 \%, 39,3 \%$ and $28.1 \%$ respectively. These crops are planted alongside the cocoa trees especially during the early stages to serve as shade for the cocoa seedling. The age at first harvest of cocoa by the respondents indicates that $85.4 \%$ of the cocoa were first harvested between the ages of 4 and 7 years, $7.9 \%$ after 7 years and 6.7 at 3years or less. This implies that predominantly most of the cocoa are first harvested at an average age of 5yars.

The reduction in years of harvesting may due to the introduction of improved cocoa hybrids. Cocoa farmers sourced for capital from their personal savings, cooperative, borrowing from friend and family while others obtaining loan with $47.3 \%, 24.7 \%, 21.3 \%$, and $6.7 \%$ respectively. Majority $(61.8 \%)$ of the cocoa farmers enjoyed the use of hired labour for their farm operations. Two-third the land used for cocoa farm was communal land while $93.3 \%$ of the seeding used was raised in nursery. Also from the table, $95.5 \%$ purchased the chemical used on their cocoa farm, but $98.9 \%$ of the cocoa farmer apply chemicals to their farm using different number/types of chemical with majority of them used type 2 chemicals.

Operations on the farm were presented in Table 3. It was observed that $52.8 \%$ of the respondents carried out weeding between 1 and 2 times a year, while $47.2 \%$ weed thrice to four times in a year with average of 2.45 . More than half $(61.8 \%)$ of the cocoa formers do not apply fertilizer to their cocoa farm while only $38.2 \%$ of them do apply. The table also indicates the number of times the respondents harvest their cocoa. More than half $(59.6 \%)$ of the farmers harvest their cocoa between 4 and 6 times in a year, with $40.4 \%$ of the respondents harvest between 1 and 3 times. The mean time of harvest is 4 times. Different types of measurements used by the farmers are equally shown in the table, about half $(48.3 \%)$ and $32.6 \%$ of the cocoa farmers used basket and kilogram respectively in measuring their cocoa, while $13.5 \%$ and5.6\% used tones and bags respectively in measuring the cocoa beans output.

Information on the problem encountered by cocoa is shown in Table 4. It was revealed that majority of the farmers $86.5 \%$ encountered multiple problems

\section{Regression Analysis}

The $\mathrm{R}^{2}=0.896$ which means $89.6 \%$ of the dependent variable is being explained by the explanatory variables. The F-value is 1.918 and it is statistically significant $(\mathrm{P}<0.1)$. The coefficient of regression associated with rent on land is 0.00000729 and it is statistically significant $(\mathrm{P}<0.1)$. This implies that rent on land is a significant determinant factor of the profitability of the cocoa farmers. It means for every acreage increase in rent on land there is going to be an increase in profit of the cocoa farmers by $\$ 72,900$. The coefficients of regression associated with cost of seedlings, cost of labour, are 0.0000188 and -0.00000988 respectively statistically significant $(\mathrm{P}<0.1)$. This implies that both cost of seedlings and cost of labour are significant determining factors of the cocoa farmers' profitability. Farmers' profitability will increase by $\$ 188,000$ with increase in cost of seed, which is not in line withaprior expectation while cost of labour will reduce the profit by $\$ 98,800$ and this is in conformity with apriori expectation. In addition, cost of chemical and tools/equipment also contributed the farmers' profitability but were not statistically significant at any level.

$\mathrm{R}^{2}=0.702 \%$ which implies that $70.2 \%$ of the cocoa farmers' productivity is being explained by the linear association between dependent (yield of cocoa) and independent variables (chemical, fertilizer, farm size, seedling, labour, age of cocoa tree, level of education and farming experience). The F. value is 2.654, which indicates the joint relationship between exogenous and endogenous variables and significant at $\mathrm{P}<0.05$. The coefficient of fertilizer is -1184.251 and it is statistically significant $(\mathrm{P}<0.05)$. it implies that fertilizer is a significant determinant factor on the cocoa farmers' productivity in the study area. It mean a unit increase in fertilizer application leads to a 1184.251 decrease in the cocoa farmers' productivity. This is not in line with increase in fertilizer should lead to increase in output. The coefficient of farm size 585.837 and it is statistically significant $(\mathrm{P}<0.01)$. it indicates that farm size is a significant determinant of the cocoa farmers' output. It also implies that a unit increase in the size of farm land used leads to a 585.837 increase in cocoa output.The coefficient of seedlings is 603.888 and is statistically significant $(\mathrm{P}<0.05)$. it means that seedlings is a significant 
determining factor in the cocoa farmers productivity/output. It implies that a unit increase in the number of seedlings leads to a 603.888 increase in the farmers output.

Table 1: Socio-Economic Characteristics of Cocoa Farmers

\begin{tabular}{|l|l|l|}
\hline Characteristics & Frequency & Percentage \\
\hline Sex & 79 & \\
Male & 10 & 88.8 \\
Female & & 11.2 \\
Age (years) & 6 & \\
20-40 & 59 & 6.7 \\
$41-60$ & 24 & 66.3 \\
>60 & & 27.0 \\
Mean: 55.40, S. D =N = 033 & 19 & \\
Level of education & 32 & 21.3 \\
No formal education & 21 & 36.0 \\
Primary & 17 & 23.6 \\
Secondary & & 19.1 \\
Tertiary & 22 & \\
Farming Experience (years) & 32 & 24.7 \\
0-15 & 23 & 36.0 \\
16-30 & 12 & 25.8 \\
31-45 & & 13.5 \\
>45 & & \\
Mean: 27.92, S. D= 15.187. & 70 & $78.7 \%$ \\
Farm size (ha) & 10 & $11.2 \%$ \\
0-3 & 9 & 10.1 \\
4-7 & & \\
>7 & & \\
Mean: 2.819, S.D = 3.075 & & 16.8 \\
Other occupation & 15 & 49.6 \\
Civil savants & 44 & 4.4 \\
Artisans & 4 & 29.2 \\
Others & 26 & 100.0 \\
No response & 89 & \\
Total & & \\
\hline 5. & & \\
\hline
\end{tabular}

Source: Field Survey, 2015.

Table 2: Input Used in cocoa production

\begin{tabular}{|c|c|c|}
\hline Characteristics & Frequency & percentage \\
\hline \multicolumn{3}{|c|}{ Age of cocoa (Years) } \\
\hline $0-20$ & 37 & 41.6 \\
\hline $21-40$ & 40 & 44.9 \\
\hline $41-60$ & 12 & 13.5 \\
\hline \multicolumn{3}{|c|}{ Mean = 26.9 SD. $=13.381$} \\
\hline \multicolumn{3}{|c|}{ Mode of land acquisition } \\
\hline Inherited & 46 & 51.7 \\
\hline Purchased & 21 & 23.6 \\
\hline Leased & 13 & 14.6 \\
\hline Others & 9 & 10.1 \\
\hline \multicolumn{3}{|c|}{ Age at first harvest (year) } \\
\hline$\leq 3$ & 6 & 6.7 \\
\hline $4-7$ & 76 & 85.4 \\
\hline$>7$ & 7 & 7.9 \\
\hline \multicolumn{3}{|c|}{ Mean $=5$ years SD. $=1.559$} \\
\hline \multicolumn{3}{|c|}{ Source of capital } \\
\hline Personal Savings & 42 & 47.3 \\
\hline Cooperative & 22 & 24.7 \\
\hline Friend and family & 19 & 21.3 \\
\hline Loan & 6 & 6.7 \\
\hline \multicolumn{3}{|l|}{ Form of Labour } \\
\hline Family & 34 & 38.2 \\
\hline Hired & 55 & 61.8 \\
\hline \multicolumn{3}{|l|}{ Land acquisition } \\
\hline Communal & 59 & 66.3 \\
\hline Leased/rent & 14 & 18.0 \\
\hline Purchased & 16 & 18.0 \\
\hline \multicolumn{3}{|l|}{ Seed Acquisition } \\
\hline Nursed & 83 & 93.3 \\
\hline Budding & 4 & 4.5 \\
\hline Others & 2 & 2.2 \\
\hline Chemical acquisit & & \\
\hline
\end{tabular}




\begin{tabular}{|l|l|l|}
\hline Purchased & 85 & 95.5 \\
\hline Gift & 2 & 2.2 \\
\hline Others & 2 & 2.3 \\
\hline Chemical application & & \\
\hline Yes & 88 & 98.9 \\
\hline No & 1 & 1.1 \\
\hline Number of chemical used & & \\
\hline None & 1 & 1.1 \\
\hline 1 type & 25 & 28.1 \\
\hline 2types & 41 & 46.1 \\
\hline 3 types & 22 & 24.7 \\
\hline Total & 89 & 100.0 \\
\hline
\end{tabular}

Source: Field Survey, 2015.

Table 3 Operation on the farm

\begin{tabular}{|l|l|l|}
\hline Characteristics & Frequency & percentage \\
\hline Times of weeding/year & 47 & \\
\hline $1-2$ & 42 & 52.8 \\
\hline $3-4$ & 89 & 47.2 \\
\hline Total & & 100.0 \\
\hline Mean $=2.45$ SD. 0.723 & & \\
\hline Fertilizer application & 34 & 38.2 \\
\hline Yes & 55 & 61.8 \\
\hline No & 89 & 100.0 \\
\hline Total & & \\
\hline Times of harvest/year & 36 & 40.3 \\
\hline $1-3$ & 53 & 59.6 \\
\hline $4-6$ & 89 & 100.0 \\
\hline Total & & \\
\hline Mean $=4.02$ SD. $=1.624$ & & \\
\hline Measure used & 0 & 0 \\
\hline Scale & 43 & 48.3 \\
\hline Basket & 29 & 32.6 \\
\hline Kilogram & 12 & 5.6 \\
\hline Tons & 5 & 100.0 \\
Bag & 89 & \\
\hline Total & & \\
\hline
\end{tabular}

Source: Field Survey, 2015

Table 4: Distribution of respondents by problems encountered

Source: Field Survey, 2015

\begin{tabular}{|l|l|l|}
\hline Problems Encountered & Frequency & Parentage \\
\hline Single Problems & 4 & $4.5 \%$ \\
\hline Double Problems & 8 & 9.0 \\
\hline Multiple Problems & 77 & 86.5 \\
\hline Total & $\mathbf{8 9}$ & $\mathbf{1 0 0 . 0}$ \\
\hline
\end{tabular}

Table 5: Regression Analysis of the Cocoa Farmers' Profitability

\begin{tabular}{|l|l|l|l|l|}
\hline Variable & Coefficient & Std error & T-value & Probability \\
\hline Constant & 12.512 & 0.167 & 74.967 & 0.000 \\
\hline Cost of chemical & $4.52 \mathrm{E}-007$ & 0.000 & 1.440 & 0.154 \\
\hline Rent on land & $7.29 \mathrm{E}-006$ & 0.000 & 1.765 & $0.081^{* * *}$ \\
\hline Tools/ equipment & $-8.14 \mathrm{E}-006$ & 0.000 & -0.593 & 0.555 \\
\hline Cost of seedlings & $1.88 \mathrm{E}-005$ & 0.000 & 1.906 & $0.060^{* * *}$ \\
\hline Cost of Labour & $-9.88 \mathrm{E}-006$ & 0.000 & -1.977 & $0.051^{* * *}$ \\
\hline
\end{tabular}

$R^{2}=0.896$ (Significant at $\mathbf{P}<0.1$ )

$\mathbf{F}=1.918 * * *=$ Significant at $10 \%$

Source: Print ant from Regression Analysis

Table 6: Regression analysis of cocoa farmers productivity

\begin{tabular}{|l|l|l|l|l|}
\hline Variable & Coefficient & Standard error & T-value & Probability \\
\hline Constant & -2905.069 & 4577.638 & -0.635 & 0.529 \\
\hline Chemical & -200.726 & 219.184 & -0.916 & 0.364 \\
\hline Fertilizer & -1184.251 & 508.841 & 2.327 & $0.024^{* * *}$ \\
\hline Farm size & 585.837 & 212.810 & 2.753 & $0.008^{*}$ \\
\hline Seedling & 603.888 & 259.631 & 2.326 & $0.024^{* * *}$ \\
\hline Labour & -92.193 & 420.245 & -0.219 & 0.827 \\
\hline Age of cocoa tree & 436.621 & 1099.543 & 0.397 & 0.693 \\
\hline Level of Education & -637.443 & 382.986 & -1.664 & 0.102 \\
\hline Farming Experience & -182.926 & 409.776 & -0.446 & 0.657 \\
\hline
\end{tabular}

$R^{2}=0.702 F=2.654$ (Significant $P<0.05$ )

*= Significant at $\mathbf{P}<0.01 * *=$ Significant at $\mathbf{P}<\mathbf{0 . 0 5}$

Source: Print out from Regression Analysis 


\section{References}

[1] Akinyemiju, O.A. (1995) "Weed management in cocoa farm" in cocoa revolution in Nigeria ed. by Adegeye A.J. and W.O.Ajayi, adaptive research, group, Ibadan, Nigerian pp. 127-128.

[2] Folayan J. A;Daramola G. A. and A. E.Oguntade(2006) Structure and Performance Evaluation of Cocoa Marketing Institutions in South-Western Nigeria: An Economic Analysis. Journal of Food, Agriculture and Environment. 2006; 4 (2): $123-128$.

[3] Komolafe et al, (1980) Agricultural science for West Africa schools and colleges, University press, Britain, chap 2.

[4] Nkang, N. M; S. O. Abang, O. E. Akpan and K. J. Offem (2006): Co-integration and Error Correction Modelling of Agricultural Export Trade in Nigeria: The case of Cocoa.Journal of Agriculture and Social Sciences.2(4): 249-255.

[5] Opeke, L. K. (1982) Tropical tree crops spectrum books limited, Ibadan, Nigeria Pp. 74-75. 